Jurnal Sistim Informasi dan Teknologi
https: //jsisfotek . org/index . php

\title{
Tingkat Pemahaman Siswa dalam Pembelajaran Daring dan Tatap Muka Langsung dalam Masa Pandemi Covid-19
}

\author{
Salmiati ${ }^{1 凶}$, Yuhandri Yunus $^{2}$, Sumijan $^{3}$ \\ ${ }^{1}$ SMP Negeri 1 Lengayang \\ ${ }^{2,3}$ Univeristas Putra Indonesia YPTK Padang \\ salmi .santi@gmai1.com
}

\begin{abstract}
The Covid-19 pandemic has a major impact on the world of education. Government policies to implement Distance Learning (PJJ) have an impact on learning in schools. Increasing ICT competence is needed to support the smooth running of PJJ. One of them is through ICT guidance activities during the Covid-19 Pandemic. SMP Negeri 1 Lengayang carried out online and face-to-face ICT guidance activities during the Covid-19 Pandemic. However, student learning outcomes in online and faceto-face learning have not shown maximum results. Various obstacles arise that affect student learning outcomes. Teachers have difficulty measuring the level of students' understanding of ICT guidance. Predicting the level of understanding of students is important as a measure of learning success during the Covid-19 Pandemic. This study aims to predict the level of understanding of students in online and face-to-face learning during the Covid-19 period, so that it can also help schools to take the right policies to improve the quality of learning for the future. This study uses the Backpropagation method of Artificial Neural Network (ANN). ANN is a part of artificial intelligence that can be used to predict. The data that is managed is a recap of the value of student cognitive learning outcomes during ICT guidance in online and face-to-face learning during the Covid-19 Pandemic. The results of calculations using the Backpropagation method with the Matlab application produce a percentage value for the level of student understanding, so that the accuracy value in prediction is obtained. With the results of testing the predictive accuracy of the level of understanding online and face-to-face with the 310-1 pattern, the best accuracy value is $95 \%$. The prediction results can measure the level of students' understanding of learning during the Covid 19 Pandemic towards ICT guidance.
\end{abstract}

Keywords: Understanding, Online Learning, Covid-19, Backpropagation Method, Information and Communication Technologies (ICT).

\begin{abstract}
Abstrak
Pandemi Covid-19 membawa dampak besar di dunia pendidikan. Kebijakan Pemerintah untuk melaksankan Pembelajaran Jarak Jauh (PJJ) berdampak pada pembelajaran di Sekolah. Peningkatan kompetensi TIK sangat diperlukan untuk mendukung kelancaran PJJ. Salah satunya dengan kegiatan bimbingan TIK dimasa Pandemi Covid-19. SMP Negeri 1 Lengayang melaksanakan kegiatan bimbingan TIK secara daring dan tatap muka langsung di masa Pandemi Covid-19. Namun hasil belajar siswa dalam pembelajaran daring dan tatap muka langsung belum menunjukkan hasil yang maksimal. Berbagai kendala muncul sehingga mempengaruhi hasil belajar siswa. Guru kesulitan untuk mengukur tingkat pemahaman siswa terhadap bimbingan TIK. Prediksi tingkat pemahaman siswa penting dilakukan sebagai tolak ukur keberhasilan pembelajaran di masa Pandemi Covid-19. Penelitian ini bertujuan untuk memprediksi tingkat pemahaman siswa dalam pembelajaran daring dan tatap muka langsung dimasa pademi covid-19, sehingga dapat pula membantu pihak sekolah untuk mengambil kebijakan yang tepat untuk meningkatkan kualitas pembelajaran untuk kedepannya. Penelitian ini menggunakan Jaringan Syaraf Tiruan (JST) metode Backpropagation. JST merupakan bagian dari kecerdasan buatan yang dapat digunakan untuk memprediksi. Data yang dikelola adalah rekap nilai hasil belajar koginitif siswa pada saat bimbingan TIK dalam pembelajaran daring dan tatap muka langsung dimasa Pandemi Covid-19. Hasil dari perhitungan dengan metode Backpropagation dengan aplikasi Matlab menghasilkan nilai persentase tingkat pemahaman siswa, sehingga diperoleh nilai akurasi dalam prediksi. Dengan hasil pengujian akurasi prediksi tingkat pemahaman secara daring dan tatap muka langsung dengan pola 3-10-1 didapatkan nilai akurasi terbaik mencapai $95 \%$. Hasil prediksi dapat mengkur tingkat pemahaman belajar siswa dimasa Pandemi Covid 19 terhadap bimbingan TIK.
\end{abstract}

Kata kunci: Pemahaman, Pembelajaaran Daring, Covid-19, Metode Backpropagation, Bimbingan TIK.

(C) 2021 JSisfotek

\section{Pendahuluan}

Teknologi Informasi dan Komunikasi (TIK) secara luas diartikan sebagai segala kegiatan yang berkaitan dengan pemprosesan, manipulasi, pengelolaan, serta pemindahan informasi antar media [1]. Pemanfaatan TIK dalam bidang pendidikan dimulai sejak berlakunya kurikulum 2004, yang mana mata pelajaran TIK bertujuan untuk meningkatkan keterampilan siswa secara lebih optimal, sehingga dapat diaplikasikan pada mata pelajaran lain sebagai lintas kurikulum [2]. Namun mata pelajaran TIK mengalami perobahan menjadi bimbingan TIK sejak berlakunya kurikulum 2013, sehingga pembelajaran TIK dilaksanakan diluar jadwal belajar secara umum [3]. Pembelajaran TIK di

Diterima: 04-03-2021 | Revisi: 30-03-2021 | Diterbitkan: 30-09-2021 | DOI: 10.37034/jsisfotek.v3i3.50 
era milineal sangat penting. Apalagi dimasa pandemi keputusan terhadap masalah baru melalui proses Corona Virus Diseases (COVID-19). Pemanfaatan TIK pemodelan atau pola data terdahulu. Backpropagation sangat menunjang kelancaran proses Pembelajaran merupakan model JST yang paling banyak Jarak Jauh (PJJ). Namun, Penyelenggaraan PJJ tidak digunakan.Salah satu kelebihan JST yaitu mampu terlepas dari berbagai persoalan seperti rendahnya mempelajari bagaimana belajar dari data yang kompetensi dalam menggunakan tekologi, biaya kuota diberikan atau melatih diri dari data awal. JST mampu internet semakin bertambah, orang tua memiliki beban merepresentasikan diri sendiri bahkan membuat suatu tambahan untuk mendampingi anaknya belajar, organisasi sendiri atau dari pengetahuan yang diterima menurunnya komunikasi antara orang tua, guru dan saat belajar [11]. Oleh sebab itu, penelitian ini memilih siswa serta waktu pembelajaran yang tiada terbatas [4]. metode Backpropagation agar dapat memprediksi

SMP Negeri I Lengayang telah melaksanakan Bimbingan TIK di masa Pandemi Covid-19. Proses tingkatpemahaman siswa terhadap bimbingan TIK dalam pembelajaran dimasa Pandemi Covid-19.

pembelajaran dilakukan secara daring dan tatap muka Sumber data yang digunakan pada penelitian ini adalah langsung. Namun pembelajaran belum terlaksana rekap nilai siswa kelas IX yang mengikuti bimbingan dengan optimal, sama halnya dengan mata pelajaran TIK di SMP Negeri 1 Lengayang pada Semester lainnya. Guru kesulitan untuk mengukur tingkat 1Tahun pelajaran 2020/202I. Data input diambil dari pemahaman belajar siswa dalam pembelajaran daring data nilai siswa kelas IX yang mengikuti bimbingan maupun tatap muka langsung. Maka penting untuk TIK dalam pembelajaran daring dan tatap muka melakukan prediksi guna mengukur tingkat langsung. Agar penelitian ini lebih terarah, maka dibuat pemahaman hasil belajar siswa, agar satuan pendidikan rumusan masalah dan batasan masalah yaitu dapat mengambil kebijakan yang tepat untuk bagaimanakah metode backpropagation mampu meningkatkan kualitas pembelajaran dimasa yang akan melakukan prediksi tingkat pemahaman belajar siswa datang.

Pada penelitian ini menggunakan Jaringan Syaraf Tiruan (JST) metode Backpropagation, untuk memprediksi hasil tingkat pemahaman siswa dalam pembelajaran dimasa pandemi Covid-19. Penerapan metode Backpropagation pada penelitian terdahulu untuk memprediksi suatu hal, diantaranya JST untuk memprediksi pengguna internet di dunia didapatkan hasil arsitektur jaringan terbaik yaitu 3-5-1 dengan tingkat akurasi $92 \%$ dan nilai Mean Squared Error (MSE) sebesar 0,00151674 [5]. JST untuk memprediksi prestasi siswa, didapatkan hasil penelitian semakin kecil tingkat ketelitian error yang digunakan maka akan Lengayang, yang beralamat di semakin kecil penyimpangan hasil JST dengan target Kambang Kecamatan Lengayang Kabupaten Pesiisr yang diinginkan [6]. JST untuk memprediksi jumlah Selatan. Jenis penelitian yang digunakan adalah siswa baru pada SMK Swasta Abdi Sejati Kerasaan, penelitian kuantitatif karena pada penelitian ini data didapatkan model arsitektur terbaik yaitu 3-2-2-1 yang digunakan adalah data berupa angka, yaitu data dengan tingkat akurasinya 75\%. MSE pelatihan nilai dari siswa kelas IX yang mengikuti bimbingan 0,000993661 serta MSE pengujian sebesar TIK dalam pembelajaran daring dan tatap muka 0,146896423 [7]. JST untuk memprediksi tingkat langsungterhadap bimbingan TIK pada Semester 1 kelulusan ujian kompetensi siswa ditemukan hasil Tahun pelajaran 2020/2021.

penelitian dengan tingkat nilai akurasi terbaik pada pola 5-6-1 mencapai 95\% [8].

Pada penelitian ini akan dikembangkan JST metode Backpropagation untuk memprediksi tingkat pemahaman siswa dalam pembelajaran daring dan tatap muka langsung terhadap bimbingan TIK.Backpropagation merupakan metode pada JST yang banyak digunakan dalam memprediksi atau peramalan. peramalan atau prediksi merupakan salah satu bidang yang dapat diaplikasikan dengan metode Backpropagation. Peramalan merupakan suatu kegiatan memperkirakan apa yang akan terjadi di masa depan dengan menggunakan kondisi atau data yang ada [9]. JST mempelajari kumpulan berbagai data terdahulu yang diibaratkan sebagai otak manusia.. Backpropagation mempunyai topologi khas dengan melibatkan tiga lapisan [10]. JST mampu memberikan

Pengumpulan data pada penelitian ini menggunakan metode studi pustaka dan wawancara.Studi pustaka dijadikan sebagai acuan untuk membantu memecahkan permasalahan pada penelitian ini. Kegiatan yang dilakukan adalah mempelajari literatur atau kajian teori yang berkaitan dengan penelitian ini. Sedangkanwawancara bertujuan untuk mendapatkan informasi yang dibutuhkan dengan cara mengajukan beberapa pertanyaan secara langsung kepada pihak Sekolah di SMP Negeri 1 Lengayang tentang pelaksanaan pembelajaran dimasa pandemi Covid-19. Sebelumnya peneliti memberikan surat izin penelitian kepada Kepala Sekolah SMP Negeri I Lengayang. Dari hasil wawancara dan pengumpulan data tersebut dilakukan pengolahan data. Berikut ini kerangka kerja penelitian yang disajikan pada Gambar 1 . 


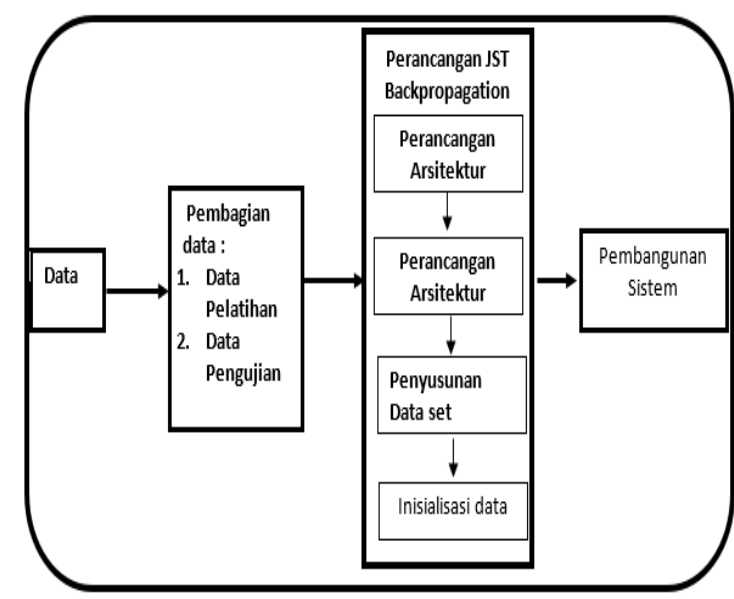

Gambar 1. Kerangka Kerja Penelitian

\subsection{Data}

Pada penelitian ini digunakan data nilai kognitif bimbingan TIK dalam pembelajaran daring dan tatap muka langsung dimasa pandemi Covid-19. Data nilai dirangkum dalam sebuah rekap data hasil belajar pada semester 1 tahun Pelajaran 2020/2021. Data didapatkan dari guru bimbingan TIK serta wawancara dengan wakil kurikulum di SMP Negeri 1 Lengayang.Selanjutnya data dan informasi tersebut diolah dengan menggunakan JST metode Backpropagation.

\subsection{Pembagian Data}

Data nilai bimbingan TIK yang telah diperoleh dikumpulkan menjadi yaitu satu kesatuan, kemudin dilakukan tahap pembagian data meliputi data pelatihan dan data pengujian. Data pelatihan digunakan untuk melatih jaringan, sedangkan data pengujian digunakan saat jaringan divalidasi.

\subsection{Perancangan Algoritma JST}

Pada tahap ini dilakukan perancangan arsitektur jaringan untuk menentukan node input (simpul Agar data dapat dikenali oleh JST, maka data tersebut masukan), jumlah lapisan layer tersembunyi dengan harus dipresentasikan dalam bentuk numerik 0 sampai jumlah nodenya (simpul hidden) dan jumlah node 1. Hal ini dikarenakan jaringan menggunakan fungsi output (simpul keluaran). Pada saat merancang aktivasi Sigmoid Biner (logsig) yang range nilainya arsitektur jaringan ditentukan pula fungsi aktivasi yang dari 0 sampai 1. Data nilai siswa yang akan digunakan akan digunakan. Maka fungsi aktivasi yang akan sebagai data pelatihan sebelumnya harus melalui tahap digunakan sesuai dengan karakteristik data yang normalisasi. Perhitungan tahap normalisasi dilakukan dimiliki [12].

\subsection{Menyusun data set untuk pelatihan dan pengujian}

Pada proses pelatihan (training) ini akan dibagi menjadi tiga fase, pertama yaitu fase maju (feedforward), fase ini akan menghitung pola masukan sampai keluaran dengan melalui fungsi aktivasi. Kemudian masuk ke fase kedua yaitu fase mundur (Backpropagation), yang berfungsi untuk menghitung ini selisih antara hasil keluaran dengan target yang telah ditetapkan, disini akan terlihat tingkat kesalahan yang terjadi [13].

\subsection{Inisialisasi data}

Tahap ini terdiri atas inisialisasi variabel learning rate, maksimum epoch dan batas nilai toleransi pelatihan Backpropagation. Epoch merupakan salah satu pembaharuan weight atau pelatihan iterasi dalam Backpropagation NeuralNetwork (BPNN) [14].

\section{Hasil dan Pembahasan}

Data uji penelitian ini yaitu data nilai bimbingan TIK pada semester1 Tahun Pelajaran 2020/2021. Data tersebut dianalisis dengan metode Backpropagation untuk memprediksi tingkat pemahaman siswa dalam pembelajaran daring dan tatap muka langsung. Ada beberapa tahapan dalam analisis metode Backpropagation seperti menetapkan nilai input, menetapkan nilai output, menentukan nilai bobot, menetapkan nilai bias, menetapkan lerning rate, dan nilai batas ambang/threashold. Hal ini dapat dijelaskan melalui Algoritma Backpropagation yang disajikan pada Gambar 2.

Analisis Metode Backpropagation:

1. Input data

2. Mengelompokkan data

3. Menyeleksi data

5. Melakukan Pelatihan dan menentukan parameter jaringan

6. Melakukan kalkulasi erorr

7. Mencari erorr terkecil

8. Melakukan proses pengujian metode backpropagation

9. Mendapatkan hasil

Gambar 1. Anaisis Metode Backpropagation

\subsection{Melakukan Normalisasi Data}

4. Melakukan iterasi disajikan pada Persamaan (1).

$$
Y n^{\prime}=\frac{0,8(y-a)}{b-a}+0.1
$$

Dimana Yn' adalah data normalisasi, y merupakan nilai datake-n, a yaitu data nilai terkecil sedangkan b adalah data nilai terbesar. Setelah tahap normalisasi selesai, dilakukan proses iterasi. Pada tahap ini data diolah menggunakan fungsi aktivasi sigmoid. Langkah-langkahnya adalah sebagai berikut:

a. Tahap initialization yaitu tahap dalam mendefinisikan awal nilai untuk variabel- 
variabel yang diperlukan seperti: nilai input, weight, output yang diinginkan, learningrate $(\alpha)$, threshold $(\theta)$ dan sebagainya.

b. Tahap activation, terdiri atas 2 langkah yaitu pada hiddenlayer dilakukan proses perhitungan actual output nya dan pada output layer dilakukan juga proses perhitungan actualoutput nya.

c. Tahap weight training, pada tahap ini memiliki 2 langkah yaitu pada out put layer dilakukan proses perhitungan error gradiaentnya, dan pada hidden layer dilakukan proses perhitungan error gradient.

d. Tahapiteration yang diartikan sebagai tahap pengujian. Ini adalah tahap terakhir yang dilakukan untuk pengujian dimana jika error yang diharapkan belum juga ditemukan maka akan kembali ke tahapan yang kedua yaitu tahap activation.

Dimana untuk melakukan perhitungan prediksi dengan metode Backpropagation, maka ditentukanvariabel input dari kumpulan nilai tugas bimbingan TIK dalam pembelajaran daring dan tatap muka langsung seperti yang disajikan pada Tabel 1 .

Tabel 1. Variabel Input

\begin{tabular}{llll}
\hline No & Variabel & Keterangan & Nilai Input \\
\hline 1 & Td & Rt.Tgs Daring & Nilai desimal \\
2 & Tm & Rt. Tgs Tatap Muka & Nilai desimal \\
3 & Rh & Rt. UH & Nilai desimal \\
\hline
\end{tabular}

Pada Tabel 1 terdapat 3 Variabel input yaitu Td, Tm dan $\mathrm{Rh}$. Setelah membuat variabel untuk inputnya, maka dilakukan pembobotan untuk output/target. Pembobotan untuk output/target disajikan pada Tabel 2.

Tabel 2. Variabel Output/ Target

\begin{tabular}{lll}
\hline No & Inisiasi & Bobot \\
\hline 1. & Paham & 1 \\
2. & Belum Paham & 0 \\
\hline
\end{tabular}

Berdasarkan tabel diatas terdapat 2 inisiasi yaitu paham dengan bobot 1 sedangkan belum paham dengan bobot 0 . Setelah itu dilakukan klasifikasi siswa yang paham dan belum paham. Pada tahap inidibentuk pola prediksi berdasarkan data kumpulan nilai ratarata tugas kognitif dalam pembelajaran daring dan tatap muka langsung yang meliputi rata-rata tugas daring, rata-rata tugas tatap muka, nilai rata-rata ulangan harian serta rata-rata dari seluruh nilai pada aspek kognitif dalam bimbingan TIK. Hasil dari pengolahan tahap ini disajikan pada Tabel 3.

Tabel 3. Data Nilai Input Untuk Pembelajaran

\begin{tabular}{ccccc}
\hline No & $\begin{array}{c}\text { RT. } \\
\text { Daring }\end{array}$ & $\begin{array}{c}\text { RT.Tatap } \\
\text { muka }\end{array}$ & RT. UH & $\begin{array}{c}\text { Rata-rata } \\
\text { (Target) }\end{array}$ \\
\hline 1 & 83,57 & 85,00 & 80 & 82,86 \\
2 & 76,43 & 80,00 & 75 & 77,14
\end{tabular}

Tabel 4. Hasil Normalisasi

\begin{tabular}{ccccc}
\hline No & Td & Tm & Rh & Y (Target) \\
\hline 1 & 0.4878 & 0.5286 & 0.3857 & 0.4673 \\
2 & 0.2837 & 0.3857 & 0.2429 & 0.3041 \\
3 & 0.3939 & 0.4143 & 0.2714 & 0.3599 \\
4 & 0.6918 & 0.6786 & 0.2714 & 0.5473 \\
5 & 0.4673 & 0.3286 & 0.3000 & 0.3653 \\
6 & 0.8959 & 0.8143 & 0.8143 & 0.8415 \\
7 & 0.5980 & 0.5643 & 0.6714 & 0.6112 \\
8 & 0.4796 & 0.5500 & 0.3857 & 0.4718 \\
9 & 0.6959 & 0.4357 & 0.3857 & 0.5058 \\
10 & 0.5286 & 0.4571 & 0.5286 & 0.5048 \\
\hline
\end{tabular}

Berdasarkan tabel diatas, maka data yang telah dinormalisasi terdiri atas sampel 10 data, kemudian pada data tersebut memiliki 3 variabel input yaitu (Td, Tm dan Rh) serta 1 variabel Output/ target yang diberi variabel y. Misalnya untuk data ke-1 memiliki nilai normalisasi $\mathrm{Td}=0,4878, \mathrm{Tm}=0,05286, \mathrm{Rh}=0,3857$ dengan nilai target 0,4673 . Selanjutnya data tersebut dilakukan proses pelatihan.

3.2 Menentukan Parameter Jaringan

Parameter yang digunakan untuk melatih jaringan adalah:

a. Jumlah hidden layer yang akan digunakan dimulai dari 8, 9, 10 layer;

b. epoch yang digunakan antara 1000-2000 dengan kenaikan setiap epochnya 200;

c. Lerning rate (Ir) yang digunakan dalam proses pelatihan ini yaitu 0,1, 0,01 dan 0,001.

d. Menggunakan target error/ goal yaitu 0,001, 0,0001 dan 0,0001 .

Setelah data dilakukan proses normalisasi data, maka dibuat arsitektur jaringan yaitu 5-10-1. Arsitektur ini terdiri dari jumlah ini untuk input layer sebanyak 3, jumlah hidden layer sebanyak 10 dan jumlah output layer sebanyak 1. Bentuk arsitektur jaringan disajikan di Gambar 3.

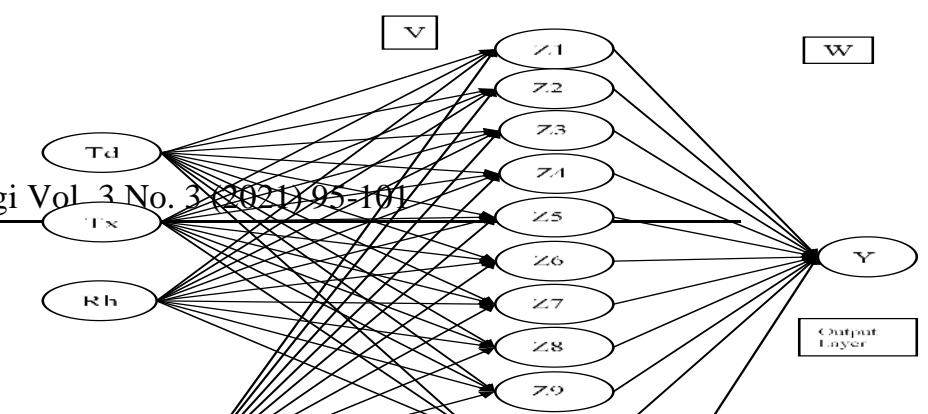


Gambar 3. Anaisis Metode Backpropagation

Berdasarkan arsitektur pada Gambar 3 didapatkan nilai bobot hidden layer yang disajikan pada Tabel 5.

Tabel 5. Nilai Bobot dan Bias Input Layer ke Hidden Layer

\begin{tabular}{lccccccccccc}
\hline & 1 & 2 & 3 & 4 & 5 & 6 & 7 & 8 & 9 \\
\hline Td & 0.487800 & 0.283700 & 0.393900 & 0.691800 & 0.467300 & 0.895900 & 0.598000 & 0.479600 & 0.695900 & 0.528600 \\
Tx & 0.528600 & 0.385700 & 0.414300 & 0.678600 & 0.328600 & 0.814300 & 0.564300 & 0.550000 & 0.435700 & 0.457100 \\
Rh & 0.385700 & 0.242900 & 0.271400 & 0.271400 & 0.300000 & 0.814300 & 0.671400 & 0.385700 & 0.385700 & 0.528600 \\
Target & 0.467347 & 0.304082 & 0.359864 & 0.547279 & 0.365306 & 0.841497 & 0.611224 & 0.471769 & 0.505782 & 0.504762 \\
\hline
\end{tabular}

Data dari Tabel 5 diproses untuk mendapatkan output layer. Nilai output layer yang dihasilkan terdapat pada Tabel 6.

Tabel 6. Nilai bobot Pada Output Layer

\begin{tabular}{ll}
\hline & $\mathrm{Y}$ \\
\hline $\mathrm{Z} 1$ & 2,99988 \\
$\mathrm{Z} 2$ & 3 \\
$\mathrm{Z} 3$ & 3 \\
$\mathrm{Z} 4$ & 3 \\
$\mathrm{Z} 5$ & 3 \\
$\mathrm{Z6}$ & 3 \\
$\mathrm{Z7}$ & 3 \\
$\mathrm{Z} 8$ & 3 \\
Bias & 2,999988 \\
\hline
\end{tabular}

Selanjutya dilakukan koreksi terhadap hasil pembobotan pada Tabel 6 berdasarkan nilai kesalahan disetiap unit keluaran.

\subsection{Pelatihan JST Backpropagation}

Pada penelitian ini digunakan software Matlab untuk membangun JST sebagaimana yang telah diuraikan pada Bagian 3.2 maka arsitektur jaringan yang terbentuk dengan aplikasi Matlab disajikan pada Gambar 4.

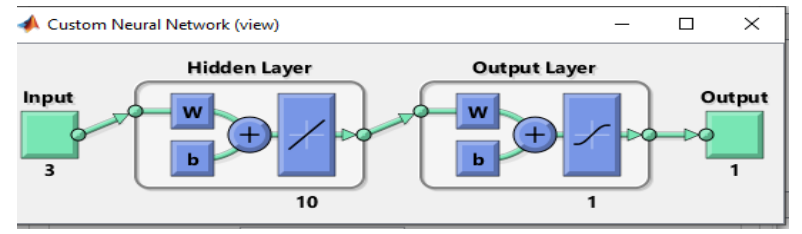

Gambar 4. Arsitektur JST Backpropagation pada Matlab
Berdasarkan Gambar arsitektur JST Backpropagation diatas, terdapat 3 bobot awal pada input menuju hidden layer, kemudian bobot dan bias dari hidden layer diterukan menuju output layer yang terbentuk secara acak oleh sistem JST yang telah dibangun tersebut. Selanjutnya dilakukan pengujian terhadap arsitektur yang telah dibangun agar nantinya didapatkan pola arsitektur terbaik yang mampu memprediksi tingkat pemahaman siswa pada pembelajaran daring dan tatap muka langsung dalam masa pandemi Covid-19.

\subsection{Proses Pengujian Metode Backpropagation}

Setelah dilakukan proses normalisasi/ transformasi data dilakukan pengujian metode Backpropagation. Arsitektur jaringan yang dibuat dengan metode Backpropagation yaitu dengan menggunakan beberapa sesuai dengan parameter jaringan yang telah diitentukan. Maka dari beberapa polaarsitektur tersebut dipilih satu pola terbaik. Maka pola arsitektur yang dipilih berdasarkan pelatihan pada software matlab adalah 3-10-1, dimana jumlah unit pada input layer ada 10 , sementara jumlah unit pada hidden layer ada 10 dan jumlah unit pada output layer ada 1 layer. Adapun arsitektur jaringan metode Backpropagation dapat dilihat pada Gambar 3 yang telah digambarkan sebelumnya.

Pada tahap pelatihan, program akan menghasilkan bobot yang akan digunakan untuk tahapan selanjutnya yaitu tahapan pengujian. Berikut ini adalah contoh perhitungan manual untuk menghitung nilai pelatihan dengan Jaringan Syaraf Tiruan untuk menentukan pola dari tingkat pemahaman siswa. Pada kasus ini menggunakan pola 3-10-1 dengan learning rate 0,1 , goal 0,01 . Untuk lebih jelasnya dapat dilihat pada penjelasan dibawah ini: Sebagai contoh pelatihan digunakan 3 buah variabel input vector $\mathrm{x}$, dari input data sebagai berikut: menggunakan fase feed forward. 


\begin{tabular}{cccc}
\multicolumn{4}{c}{ Tabel 7. Input Data } \\
\hline No & $\mathrm{Td}_{1}$ & $\mathrm{Tm}_{1}$ & $\mathrm{Rh}_{1}$ \\
\hline 1 & 0.5522 & 0.5157 & 0.4257 \\
\hline
\end{tabular}

Dari tabel diatas, terdapat nilai $\operatorname{Td}_{1}=0,5522$, $\mathrm{Tm}_{\underline{1}}=0,5157$, dan $\mathrm{Rh}=0,4257$. Setelah hasil transformasi diketahui kemudian langkah selanjunya adalah menetapkan nilai input, nilai target, learning rate $(\alpha)$, dan epoch. Berikut ini analisa masalah dengan menggunakan arsitektur 3-10-1 :

Iterasi 1

\section{Fase Feedforward}

Tahap Initialization.

Berdasarkan data pada Tabel 7, maka dapat dilakukan Fase Backforward: fase feed forward dengan Learning rate $(\alpha)=0,01$

Selanjutnya menghitung semua nilai output pada hidden layer dengan Persamaan (2).

$$
\begin{aligned}
& Z_{-} \text {net }_{j=V_{j 0}}+\sum_{i=1}^{n} \text { Xi Vji (2) } \\
& \text { Z_net }_{1}=6.324463 \\
& \text { Z_net }_{2}=5,823038 \\
& \text { Z_net }_{3}=5,144028
\end{aligned}
$$

$$
\begin{aligned}
& 0.5)+(0.611224 *-0,5)+(0.471769 *-0.5)+ \\
& 0.5)+(0.504762 *-0.5) \\
& y_{\text {netl }}=-12
\end{aligned}
$$

Maka dari penghitungan diatas, didapatkan nilai jumlah semua sinyal aktual pada hidden layer yaitu: -12

Hitung semua output aktual pada output layer dengan persamaan berikut:

$$
\begin{aligned}
& y_{j}=f\left(y_{\text {net }_{k}}\right)=\frac{1}{\alpha+e^{-y_{-} \text {net } k}} \\
& y_{1}=f\left(y_{\text {net }_{1}}\right)=\frac{1}{1+e^{-(-12)}}=0.0769
\end{aligned}
$$

Maka nilai outputaktual pada outputlayer adalah 0,0769

\section{Tahap Weigh Training}

Yaitu menjumlahkan error gradient pada output layer berdasarkan nilai kesalahan disetiap unit keluaran, menggunakan persamaan berikut, yaitu:

$$
\begin{aligned}
& \delta k=\delta=(t-y) y(1-y) \\
& \delta k 1=\delta=(0.1000-0.0769) 0.0769(1-0.0769) \\
& \delta k 1=(0,0016)
\end{aligned}
$$

Selanjutnya hitung Output aktual pada Hidden Layer Maka pada tahap ini didapatkan hasil error gradient menggunakan fungsi aktivasi, dengan persamaan berikut yaitu:

$$
\begin{aligned}
& Z_{j}=f\left(Z_{\text {net }_{j}}\right)=\frac{1}{1+e^{-z_{-} \text {net } j}} \\
& Z 1=f(2.99988)=\frac{1}{1+e^{-(2.99988)}}=-0.50003 \\
& Z 2=-0.5 \\
& Z 3=-0.5 \\
& Z 4=-0.5 \\
& Z 5=-0.5 \\
& Z 6=-0.5 \\
& Z 7=-0.5 \\
& Z 8=-0,5 \\
& Z 9=-0.5 \\
& Z 10=-0.5
\end{aligned}
$$

Dari persamaan diatas, didapatkan hasil output aktual pada hiddenlayer yaitu yaitu - 0.5

Selanjutnya jumlahkan semua sinyal yang masuk ke unit output dengan persamaan (4).

$$
\begin{aligned}
& y_{\text {net } k}=w_{k o}+\sum_{j}^{p}=1_{Z j W k}(4) \\
& y n e t 1=W 0+(\mathrm{W} 1 * \mathrm{Z} 1)+(\mathrm{W} 2 * \mathrm{Z} 2)+(\mathrm{W} 3 * \mathrm{Z} 3) \\
& +(\mathrm{W} 4 * \mathrm{Z} 4)+(\mathrm{W} 5 * \mathrm{Z} 5)+(\mathrm{W} 6 * \mathrm{Z} 6)+(\mathrm{W} 7 * \mathrm{Z} 7)+(\mathrm{W} 8 * \mathrm{Z} 8) \\
& +(\mathrm{W} 9 * \mathrm{Z} 9)+(\mathrm{W} 10 * \mathrm{Z} 10) \\
& y_{\text {net } 1}=3.000+(0.467347 *-0.5)+(0.304082 *(-0,5)+( \\
& 0.547279 *-0.5)+(0.365306 *-0.5)+(0.841497+-
\end{aligned}
$$

pada output layer sebesar 0,060 . Hasil pengujian secara manual tersebut, akan dibandingkan dengan pengujian dengan software matlab, sehingga dapat diketahui pola arsitektur terbaik untuk memprediksi tingkat pemahaman siswa.

\section{Kesimpulan}

Setelah melakukan tahapan proses penelitian mengenai tingkat pemahaman siswa dalam pembelajaran daring dan tatap muka langsung dalam masa pandemi Covid19, maka disimpulkan bahwa Metode Backpropagation dapat digunakan untuk memprediksi tingkat pemahaman siswa terhadap bimbingan TIK dengan pola arsitektur 5-10-1 dengan tingkat akurasi yaitu 95\%. Sehingga penelitian ini dapat dijadikan rekomendasi dalam penentuan tingkat pemahaman siswa dimasa yang akan datang.

\section{Daftar Rujukan}

[1] Huda, I. A. (2020). Perkembangan Teknologi Informasi dan Komunikasi (TIK) Terhadap Kualitas Pembelajaran di Sekolah. Jurnal Pendidikan dan Konseling, 2(1), 143-149.

[2] Budiman, H. (2017). Peran Teknologi Informasi dan Komunikasi dalam Pendidikan. Al-Tadzkiyyah: Jurnal Pendidikan Islam, 8(I), 31-43. DOI: https://doi.org/10.24042/atjpi.v8i1.2095 .

[3] Chandra, M., Yuhandri, Y., \& Na'am, J. (2019). Penentuan Materi Layanan Bimbingan TIK Menggunakan Algoritma C4.5. Jurnal KomtekInfo, 6(1), 19- 28.

[4] Setyorini, I. (2020). Pandemi Covid-19 dan Online Learning: Apakah Berpengaruh Terhadap Proses Pembelajaran Pada Kurukulum 13?. Journal of Industrial Engineering \& Management Research (JIEMAR), 1(1).

[5] Setti, S., Wanto, A., Syafiq, M., Andriano, A., \& Sihotang, B. K. (2019). Analysis of Backpropagation Algorithms In Predicting 
World Internet Users. Journal of Physics: Conference Series, 1255. DOI: https://doi.org/10.1088/1742-6596/1255/1/012018 .

[6] Zola, F. (2018). Jaringan Syaraf Tiruan Menggunakan Algoritma Backpropagation Untuk Memprediksi Prestasi Siswa. Jurnal Teknologi dan Open Source, 1(1), 58-72. DOI: https://doi.org/10.36378/jtos.v1i1.12 .

[7] Simatupang, N. I., Sitohang, S. R. I., Situmorang, A. P., \& Simatupang, I. M. (2020). Efektivitas Pelaksanaan Pengajaran Online Pada Masa Pandemi Covid-19 dengan Metode Survey Sederhana. Jurnal Dinamika Pendidikan, 13(2), 197-203.

[8] Syofneri, N., Defit, S., \& Sumijan. (2019). Implementasi Metode Backpropagation untuk Memprediksi Tingkat Kelulusan Uji Kopetensi Siswa. Jurnal Informasi dan Teknologi, 1(4), 12-17. DOI: https://doi.org/10.37034/jidt.v1i4.13 .

[9] Lubis, M. R. (2019). Model Jaringan Saraf Tiruan Backpropagation Untuk Meningkatkan Penguasaan Mahasiswa Pada Matakuliah Algoritma dan Pemrograman. Paradigma Jurnal Komputer dan Informatika, 21(1), 91-94. DOI: https://doi.org/10.31294/p.v21i1.5079 .

[10]Hutabarat, M. A. P., Handrizal, \& Jalaluddin. (2020). Penerapan Algoritma Backpropagation dalam Memprediksi Jumlah
Penduduk di Kecamatan Pematang Bandar Berdasarkan Nagori/Kelurahan. Journal of Information System Research (JOSH), 1(2), 63-69.

[11]Nafi'iyah, N., Ahmad, R. A., \& Mujilahwati, S. (2020). Prediksi Nilai Calon Mahasiswa dengan Algoritma Backpropagation (Studi Kasus: Data Kaggle). Jurnal Nasional Komputasi dan Teknologi Informasi (JNKTI), 3(1), 9-17. DOI: https://doi.org/10.32672/jnkti.v3i1.1945

[12] Apriyani, Y. (2018). Penerapan Jaringan Syaraf Tiruan Backpropagation Untuk Prediksi Nilai UN Siswa SMPN 2 Cihaurbeuti. IJCIT (Indonesian Journal on Computer and Information Technology), 3(1), 63-70.

[13] Solikhun, S., Safii, M., \& Trisno, A. (2017). Jaringan Saraf Tiruan Untuk Memprediksi Tingkat Pemahaman Sisiwa Terhadap Mata Pelajaran dengan Menggunakan Algoritma Backpropagation. J-SAKTI (Jurnal Sains Komputer dan Informatika), 1(1). DOI: https://doi.org/10.30645/j-sakti.v1i1.26 .

[14]Fitriadini, A., Pramiyati, T., \& Pangaribuan, A. B. (2020). Penerapan Backpropagation Neural Network dalam Prediksi Harga Saham. Seminar Nasional Mahasiswa Ilmu Komputer dan Aplikasinya

(SENAMIKA). 